\title{
PERCEPÇÃO DISFUNCIONAL DO AGRESSOR NA LEI MARIA DA PENHA: TOLERÂNCIA E INVISIBILIDADE NUM SISTEMA DE CONTINUIDADES
}

\author{
Regina Lúcia Gonçalves Tavares ${ }^{1}$ \\ Artenira da Silva e Silva ${ }^{2}$
}

\begin{abstract}
Resumo
Este trabalho busca examinar a percepção disfuncional do Poder Judiciário da figura do agressor doméstico e de como isto corrobora num subaproveitamento das garantias consignadas na Lei 11.340/06. Explora os obstáculos observados em relação àquele sistema de justiça para apropriar-se da norma em espécie, avaliando seu protagonismo em acessar e fazer funcionar as Redes de Atendimento à mulher em situação de violência. Descortina a existência de uma cultura jurídica normativista e técnico-burocrata a partir de dados empíricos presentes na análise de uma decisão de revogação de prisão preventiva de um agressor doméstico e seus desdobramentos. A metodologia consiste em pesquisa bibliográfica e documental. O problema que se coloca neste trabalho é: com que clareza a magistratura lida com os mecanismos adotados para a punição, prevenção e erradicação da violência contra a mulher?
\end{abstract}

Palavras-chave: Lei Maria da Penha. Violência de gênero. Invisibilidade do agressor. Assistência integral. Redes de Serviços.

\section{INTRODUÇÃO}

Em agosto de 2015, A. C. C., inconformado com o fim do relacionamento, sequestrou a ex-namorada M. N. S. S., mantendo-a em cárcere privado para, em seguida, assassiná-la com um tiro no ouvido e atirar contra a própria cabeça matando-se. O desfecho trágico desta história se deu após A. C. C. ter sido libertado da prisão preventiva a ele imposta em razão de, um mês antes, ter sequestrado e mantido a ex-namorada presa em uma casa por dez horas, tendo isto feito por não concordar com o fim do namoro (JORNAL O IMPARCIAL, 2015).

Em razão da grande repercussão na imprensa sobre o caso, manifestou-se a Associação dos Magistrados justificando ter sido decretada a liberdade provisória de A. C. C. ante o fato de ser o mesmo primário, ter bons antecedentes, endereço fixo e necessitar se submeter a tratamento para depressão e, ainda, vir a corroborar com

\footnotetext{
${ }^{1}$ Mestranda em Direito e Instituições do Sistema de Justiça pela Universidade Federal do Maranhão (PGPP-UFMA). Professora da Universidade Ceuma. E-mail: rlg.t@hotmail.com

2 Pós-doutorado em Psicologia e Educação pela Universidade do Porto, Portugal. Professora adjunta e pesquisadora da Universidade Federal do Maranhão. E-mail: artenirassilva@hotmail.com
} 
esta constatação o fato de a vítima ter comparecido em juízo para declarar que não se sentia ameaçada e, portanto, intervir para liberação do preso, a fim de que fosse o mesmo submetido a tratamento adequado (ASSOCIAÇÃO DOS MAGISTRADOS DO MARANHÃO, 2015).

O cruel desfecho deste caso nos revela o ainda extenso e penoso caminho que a Lei 11.340/06, chamada Lei Maria da Penha (BRASIL, 2006), precisa trilhar para que seja efetiva e eficazmente aplicada.

Não é possível aqui construir, a partir dos fatos do cotidiano conjugal, a dinâmica relacional que foi mantida entre A. C. C. e M. N. S. S, bem como se definir a partir de quais mecanismos de subjugação esta se tornou obsessiva, violenta e destrutiva, mas é possível vislumbrar que, neste processo de deterioração, estão articuladas a violência psicológica e a violência física, a colocar ambos, mulher e homem, num processo de sofrimento e deflagrar uma engrenagem de outras violências baseadas em gênero que se agravaram até o trágico desfecho ora narrado.

Requerendo a revogação de sua prisão preventiva, A. C. C. assim o fez afirmando ser primário, ter bons antecedentes, residência fixa e, ainda, necessitar se submeter a tratamento para depressão, pelo que deveria permanecer aos cuidados de um irmão, residente em cidade contígua (TJMA/2015, s/p).

Atendendo ao requerimento do réu, a decisão que determinou a soltura de A. C. C. fixou, além das formalidades de praxe, a condição de o mesmo "juntar ao feito comprovante do inicio do tratamento médico em 10 dias" (TJMA/2015, s/p).

Com efeito, o quadro acima aponta para uma conjuntura na qual, antes de tirar a vida de M. N. S. S. e a sua própria, A. C. C. afirmava estar deprimido, razão inclusive pela qual, segundo noticia a Associação dos Magistrados (AMMA, 20015), contribuiu fortemente para sua soltura, já que o mesmo carecia de tratamento médico.

Aqui, seria necessário não subestimar o suposto quadro de depressão do agressor, este, provavelmente, refluxo de um processo de conflito interno que, a sua vez, poderia estar retroalimentando seu comportamento agressivo e de controle em relação à vítima. Esta última assediada por atos de violência de gênero que mais tarde resultariam em sua morte.

Não se trata de um quadro banal, pelo contrário, é fato que demanda uma análise acerca da postura do Poder Judiciário em relação à percepção dialética que move as complexas relações pautadas em violência doméstica, sobretudo com foco no comportamento agressor, frequentemente fora do controle dele mesmo.

Para tanto, faz-se necessário ultrapassar barreiras disciplinares que, na visão de Segato (2003), obstaculizariam uma abordagem de dimensão sociopsicológica da violência, que assim a signifique para além da dicotomia macho e fêmea, portanto antropologicamente transcendente aos signos de dominação patriarcal e, por isto mesmo, mas eficiente em prevenir, erradicar e punir a violência contra a mulher mediante a contribuição 
paritária de outros significantes:

Deste ponto de vista, é possível interpretar o que eles mesmos tentam dizer em entrevistas quando dizem, repetidamente, que "não era eu" ou "era eu, mas um outro me fez agir", "ele era algo, alguém mais", onde a instituição judicial cobra uma indiscutível corporeidade e um poder determinante: álcool, drogas, o diabo, um espírito que "tomou corpo," um companheiro e, até mesmo, em um dos casos, um verdadeiro agressor, com nome e sobrenome, que segundo o inquérito foi inventado pelo réu. Com estes álibis, simplesmente o estuprador não trata meramente de mentir ou ilidir sua culpa. Mas exatamente, tenta descrever ou examinar a experiência de uma falta de autonomia que o deixa perplexo; os outros, dentro de sua consciência, por vezes, falam mais alto que sua própria razão propriamente subjetiva. Esta escuta rigorosa das palavras é fundamental para compreender um tipo de crime cujo significado escapa a racionalidade não só do investigador, mas também dos seus autores, apenas porque a sua lógica não se esgota no indivíduo, mas vem de um campo intersubjetivo, que se deve ter em conta para fazer com que o ato, a "burrada", como dizem em alguns casos, seja inteligível. (SEGATO, 2003, p. 36) (tradução nossa) ${ }^{3}$

Por outro lado, percebe-se que, uma vez nitidamente cooptadas, o desenrolar da violência psicológica e da violência física nos contornos do caso ora narrado, demonstra que o enfrentamento da situação centrou-se basicamente em sua manifestação aguda, qual seja o fato de a prisão do agressor não se achar conforme o princípio de presunção da inocência, inscrito no artigo 5o, inciso LVII, da Constituição Federal.

O fato de ambos, algoz e vítima, estarem inseridos em um contexto de violência psicológica e física - isto muito bem esboçado com o reconhecimento do estado depressivo do agressor e a subjugação emocional da vítima que, outrora submetida a 10 horas de cárcere privado, declarou não se sentir ameaçada (AMMA, 20015) -, foi dado negligenciado por parte dos sistemas de segurança e justiça.

É o que Silva, Coelho e Caponi, consideram em artigo sobre o tema da violência psicológica a afetar ambos os lados de quem a vivencia e seu trato negligenciado (SILVA; COELHO; CAPONI, 2007):

Embora seja difícil entender a ocorrência da violência física sem a presença da violência psicológica, que é tão ou mais grave que a primeira, muitos artigos nem sequer citam a sua existência. Vale ressaltar que não está sendo, aqui, descartada a possibilidade da ocorrência da violência física sem que a violência psicológica a preceda, mesmo se constatando que a maioria dos casos demonstre o contrário. Esta aparente indiferença dos pesquisadores em escrever sobre este fenômeno é o segundo pilar referido anteriormente, que reforça a afirmação inicial sobre a prioridade dada para a violência que provoca consequências físicas graves em detrimento das graves consequências psicológicas. Tem-se, assim, uma dupla omissão da violência psicológica: a falta de referência ao fato na mídia e os poucos estudos existentes sobre o tema.

\footnotetext{
${ }^{3}$ Texto original: "Desde este punto de vista, es posible interpretar lo que ellos mismos intentan decir en las entrevistas realizadas cuando afirman, reiteradas veces, que "no fui yo" o "fui yo, pero otro me lo hacía hacer", "había algo, alguien más", cuya agencia cobra una indiscutible corporeidad y un poder determinante: alcohol, droga, el diablo, un espíritu que "cobró cuerpo", un compañero e incluso, en uno de los casos, un verdadero autor del delito, con nombre y apellido, que según el prontuario fue inventado por el reo. Con estas coartadas, el violador no trata simplcmente de mentir o eludir su culpabilidad. Más exactamente, intenta describir y examinar la experiencia de una falta de autonomía que lo deja perplejo; los otros, dentro de su conciencia, hablan a veces más alto que su razón propiamente subjetiva. Esta escucha rigurosa de las palabras es fundamental para comprender un tipo de delito cuyo sentido escapa a la racionalidade no sólo del investigador sino también de sus propios autores, justamente porque su razón de ser no se agota en el individuo sino que procede de um campo intersubjetivo que debe tomarse en cuenta para hacer que su acto, su "burrada", como dicen en algunas ocasiones, sea inteligible." (SEGATO, 2003, p. 36)
} 
Em razão das diversidades conceituais abordadas, pode-se dizer que a proposta central do presente trabalho é a de delinear o alcance da Lei Maria da Penha, e suas interfaces transdisciplinares, no que tange à percepção do agressor, em atenção às suas necessidades de atendimento integral, com base no que prescreve a Lei 11.340/06, como forma de prevenir e/ou coibir violências futuras e, consequentemente, dar efetiva proteção à mulher inserida em situação de violência de gênero.

Para a compreensão do sentido teórico-prático desta ação integral, parte a presente análise de um caso concreto, ocorrido no Maranhão, cuja repercussão atingiu sobremaneira a imprensa, a sociedade e, de igual forma, a academia, por ser emblemático no sentido de exibir o modo através do qual os ambientes judicial e extrajudicial lidam com a percepção e enfrentamento das violências domésticas perpetradas contra mulheres, especificamente no que tange à invisibilidade das especificidades que caracterizam este tipo de agressor.

Aqui, leva-se em conta a própria dificuldade evidenciada na composição de políticas de acolhimento destas situações de violência por parte do Estado.

Em contrapartida, este estudo busca revelar o distanciamento do Judiciário em relação à Rede de Proteção à mulher em situação de violência e a maneira com a qual decide acerca daqueles casos.

A partir do exame da decisão que deferiu a liberdade provisória do réu, no estudo de caso aqui proposto, é possível tomá-la como bastante significativa para evidenciar dois grandes obstáculos.

O primeiro deles confirma a deficiência do Judiciário no que tange à capacidade de demonstrar domínio de conhecimento específico acerca dos fenômenos de violência doméstica e de violência de gênero, o que se acha demonstrado pelo próprio conteúdo daquela decisão.

O segundo revela a dificuldade do Judiciário em identificar a atuação do Serviço de Responsabilização e Educação do Agressor da Rede de Atendimento e de Enfrentamento à Violência contra as Mulheres (BRASIL, 2011), assim carecendo de uma maior percepção dos atores que integram a Rede de Proteção, ainda que diante da constatação de sua tímida implantação no cenário nacional, notadamente no cenário do Estado do Maranhão

Com efeito, a atuação do judiciário, como integrante da Rede de Proteção à mulher em situação de violência, deve atentar para as variáveis decorrentes das políticas locais de tutela e proteção da vítima, como aquelas porventura existentes em seu espaço de atuação, numa perspectiva de que, em se tratando no manejo da Lei Maria da Penha, suas decisões encontrem eco na estrutura da referida Rede.

Com efeito, a decretação da liberdade provisória de um agressor doméstico, sob a chancela da Lei Maria da Penha conforme feito, ou seja, dentro de uma conjuntura que expõe agressor e vítima à dinâmica cíclica desta

\footnotetext{
${ }^{4}$ Os entraves relativos à execução penal dificultam a efetividade da Lei Maria da Penha no Maranhão, de acordo com a promotora de Justiça Márcia Haydée Porto de Carvalho. Ela citou a inexistência de centro de ressocialização para os agressores e da casa de albergado como elementos dificultadores da aplicação integral da lei. "A falta de um espaço adequado dificulta a punição dos agressores. A ausência da casa do albergado força a Justiça a converter as penas dos condenados para o regime domiciliar”.
} 
espécie de violência, indubitavelmente revela fragilidades que tornam cada vez mais vulnerável a mulher ao fenômeno da violência de gênero.

Seu enfrentamento demanda artifícios que possibilitem conjugar o Estatuto Processual Penal às nuances de um tipo penal que se manifesta, como dito, de forma cíclica e peculiar, e que pode ainda reatualizar-se em reproduções que levem inclusive ao feminicídio ${ }^{5}$ (forma mais grave de violência dentro do espectro dos crimes cometidos contra a mulher), este o triste desfecho da história de A. C. C. e M. N. S. S.

Valendo-se de um caso emblemático que é hábil em revelar não só as descontinuidades na atuação do Poder Judiciário junto à Rede de Proteção, mas também certa disfunção na percepção da figura do agressor, este trabalho resgata a importância de se problematizar transdisciplinarmente o fenômeno da violência de gênero, para tanto apontando um subaproveitamento das garantias consignadas na Lei 11.340/06.

O referencial teórico mobilizado se sustenta nos estudos de gênero de Segato (2003), Pougy (2010), Pasinato (2010) Celmer e de Azevedo (2007), entre outros, associado aos estudos acerca da sociedade de Rouland (2008) e da atuação do Judiciário de Santos (2007). A metodologia é constituída de pesquisa bibliográfica e documental; as análises são de base qualitativa e o corpus compõe-se de uma decisão de revogação de prisão preventiva de um agressor doméstico de mulher, registrado no sítio eletrônico do Tribunal de Justiça do Maranhão.

O problema destas reflexões se apresenta de forma a buscar responder com que clareza a magistratura lida com os mecanismos adotados para a punição, prevenção e erradicação da violência contra a mulher, com isto evitando que se deflagre uma escalada de abusos e/ou negligências e omissões que ponham em risco a vida da mulher submetida a seus efeitos.

\section{OS DESAFIOS METODOLÓGICOS NO TRATO DA VIOLÊNCIA DE GÊNERO}

A inserção de um estatuto legal do porte da Lei 11.340/06, chamada Lei Maria da Penha, no cenário político brasileiro trouxe a reboque importantes discussões acerca do alcance e da eficiência daquela norma,

\footnotetext{
(MINISTÉRIO PÚBLICO DO MARANHÃO, 2015)

${ }^{5}$ Código Penal (BRASIL, 1940)

Art. 121. Matar alguém:

Pena - reclusão, de seis a vinte anos.

(...)

$\$ 2^{\circ}$ Se o homicídio é cometido:

(...)

VI - contra a mulher por razões da condição de sexo feminino

Pena - reclusão, de doze a trinta anos.

\2º-A Considera-se que há razões de condição de sexo feminino quando o crime envolve:

I - violência doméstica e familiar;

II - menosprezo ou discriminação à condição de mulher.
} 
sobretudo quanto ao enfrentamento das questões relacionadas à violência doméstica.

De fato, a Lei Maria da Penha resultou do reconhecimento formal de ser a violência contra mulher um problema social a exigir enfrentamento mais drástico por parte de nosso legislador que, ao seu turno, deveria lançar sobre o aludido fenômeno um olhar de maior gravidade.

Trata-se de espécie de violência cujo enfrentamento demanda uma maior compreensão de suas nuances, numa perspectiva que permita distingui-la daqueles outros tipos praticados fora de um contexto em que vítima e agressor estejam envolvidos numa relação de afetividade ou de proximidade.

A partir da edição daquela norma, as diversas formas de violência praticadas contra a mulher no ambiente doméstico deixaram de ser albergadas pelo microssistema da Lei 9.099/95 (BRASIL, 1995) e, divorciadas de um tratamento jurídico que as conjugava como crimes de menor potencial ofensivo, estes punidos mediante uma sistemática de penalidades alternativas e simbólicas, doravante passaram a ser enfrentadas por uma metodologia punitiva mais rigorosa e sensível às peculiaridades do tipo penal em questão.

A Lei 11.340/2006 desvincula a representação da vítima à propositura da ação penal pelo Ministério Público em casos de lesão corporal leve ou culposa, resultante de violência doméstica, familiar ou íntima; acresce a pena aplicada à prática de lesão corporal, inclusive impondo-lhe qualificadora, quando se tratar de violência doméstica, aumentando-a para um intervalo de três meses a três anos, e com isto modificando o artigo 129, $\$ 9^{\circ}$, do Código de Processo Penal (BRASIL, 1941), que previa pena de seis meses a um ano.

Veta ainda a lei a substituição da pena privativa de liberdade por penas restritivas de direitos, bem como as penas de fornecimento de cestas básicas ou outras de prestações pecuniárias e, ainda, prevê a concessão de medidas protetivas de urgência, a fim de resguardar a incolumidade da ofendida.

Compreendendo a importância de seu objeto, pode-se afirmar que a Lei Maria da Penha, por sua própria função, é norma que se situa no campo dos direitos humanos e atende a um projeto de estatura Constitucional, qual seja aquele previsto no artigo 226, $\$ 8^{\circ}$ da Constituição Federal: "O Estado assegurará a assistência à família na pessoa de cada um dos que a integram, criando mecanismos para coibir a violência no âmbito de suas relações".

Com efeito, a referida lei é fruto de uma construção que, tocada por pressões internacionais ${ }^{6}$, deflagradas pela renitência do Brasil em enfrentar de maneira mais contundente a questão da violência de gênero, traduziu o anseio de se estabelecer uma ação normativa que formalmente reconhecesse a gravidade das violências sofridas pela mulher em seu ambiente privado, como agressões que deflagram a desconstrução de sua personalidade, numa escalada de abusos que podem chegar até ao seu assassinato.

Norbert Rouland (ROULAND, 2008, p.23) compreende que o Direito é construção cultural do

\footnotetext{
${ }^{6}$ Convenção sobre a Eliminação de Todas as Formas de Discriminação contra as Mulheres (CEDAW, ONU, 1979), Convenção Interamericana para prevenir, Punir e Erradicar a Violência contra a Mulher (Convenção de Belém do Pará, OEA, 1994)
} 
homem e, por isto, sua elaboração e aperfeiçoamento remontam à relação do homem com o seu meio. Entende o autor que a ideia que o homem faz do direito, depende do sentido que dá ao mundo.

De fato, diante do cenário internacional, achava-se o Brasil constrangido ante a demora em formular um modelo legal específico de enfrentamento da violência contra a mulher, assim protagonizando, por omissão, um hiato legislativo que revelava, de per si, uma agressão a um direito humano de inquestionável importância.

Considerando a Convenção sobre a Eliminação de Todas as Formas de Discriminação contra as Mulheres (CEDAW, ONU) realizada no ano 1979 e promulgada no Brasil pelo Decreto 89.460/1984 e, ainda, a Convenção Interamericana para Prevenir, Punir e Erradicar a Violência contra a Mulher (Convenção de Belém do Pará, OEA), esta realizada em 1994, a edição da Lei 11.340/06 (Lei Maria da Penha) somente no ano de 2006 é dado capaz de visibilizar nossa estrutura de dominação historicamente patriarcal, a demarcar a construção de nossos valores e, por via reflexa, conjecturar sobre a tradição do Poder Judiciário, no que tange ao enfrentamento da violência de gênero.

É visível que os movimentos feministas no Brasil, protagonistas de lutas que trouxeram como conquista uma legislação protetiva, que vem ao encontro da compreensão do direito da mulher como um direito humano, tem encontrado, por diversas vezes no Judiciário, um monólogo dissonante, distanciado, e conservador:

As reflexões apresentadas parecem levar a um prognóstico pessimista quanto à instrumentalidade e eficácia das estratégias jurídico-políticas promovidas para o combate à violência de gênero. Estaríamos desembocando na evidência de um «fetichismo legal» inadequado para enfrentamento desse problema social? Teriam sido ineficazes ou de reduzido impacto essas mobilizações feministas que se debruçaram na luta por mudanças no direito, enquanto instrumento de poder capaz de reproduzir os discursos androcêntricos e sexistas que banalizam a violência que afeta as mulheres? Diremos que não. Até mesmo porque a resposta para os casos de violência doméstica não se esgota no direito, e outras áreas têm sido mobilizadas para tratamento desse tipo de conflito. (SCIAMMARELLA; FRAGALE FILHO, 2015)

Fazia-se fundamental que, nos casos em que a violência se materializa em detrimento da condição da mulher, no âmbito das relações conjugais e de afeto, houvesse por parte do sistema jurídico brasileiro uma ação que atendesse maiores necessidades de regulação e de se fazer justiça.

Atente-se ao fato de que a aplicação da Lei Maria da Penha demanda que cada ator da Rede deve atuar no sentido de extrair da referida lei todo seu potencial protetivo, atento - contudo não co-dependente -, à atuação dos demais que a integram.

Publicada a Lei Maria da Penha em 22 de setembro, de 2006 e lá definidas as espécies de violência que tal instrumento busca punir, prevenir e coibir, seu manejo, percebe-se, ainda se dá timidamente por parte das instituições do sistema de justiça e segurança pública.

Naquele estatuto foram previstas as formas da violência doméstica contra a mulher como física, psicológica, sexual, patrimonial e moral, estas situadas tanto na unidade doméstica, quanto na família ou nas 
relações íntimas de afeto.

Prevê a referida Lei, em seu artigo $8^{\circ}$, a definição de políticas públicas com intuito de coibir a violência doméstica e familiar contra a mulher, a serem implementadas mediante um conjunto articulado de ações empreendidas pela União, os Estados, o Distrito Federal e os Municípios, bem como por entidades nãogovernamentais tais como os Centros de Referência de Atendimento à Mulher e Centros de Referência Especializada da Assistência Social, com papel de oferecerem ajuda psicológica e social para os envolvidos nestes casos de violência.

Segundo Wânia Pasinato (PASINATO, 2010), para coibir e prevenir a violência doméstica e familiar contra a mulher, a Lei Maria da Penha tem suas ações organizadas em três eixos de intervenção, quais sejam medidas criminais propriamente ditas para a punição da violência em espécie, executadas pelo procedimento penal persecutivo do delito; medidas de proteção da integridade física e dos direitos da mulher, deflagradas pelo conjunto de medidas protetivas voltadas a resguardar sua segurança, bem como a assistência integral à mulher em situação de violência; por fim as medidas de prevenção e educação como forma de conscientização da sociedade acerca da violência e da discriminação baseadas no gênero.

Muito embora estejam os três eixos intrinsecamente interrelacionados, o foco deste trabalho é o segundo eixo de intervenção, qual seja aquele que se relaciona com o resguardo da integridade física e dos direitos da mulher, mais especificamente aquele que prediz a assistência integral à mulher em situação de violência.

Busca-se a compreensão dos mecanismos que enfrentem a continuidade e especificidade das situações de violência doméstica e as formas legais de evitar sua cristalização, com foco na desconstrução de formas institucionais de desprestígio da mulher agredida e da subestimação do potencial lesivo da agressão - seja ela física ou psicológica - e do agressor. Neste último caso, permitindo a percepção de suas singularidades enquanto agressor doméstico por parte dos sujeitos envolvidos.

A assistência integral à mulher em situação de violência no âmbito das relações conjugais pode ser concebida como uma trama de serviços que permita a percepção daquele fenômeno através da articulação de intervenções que efetivamente viabilizem seu enfrentamento:

Na configuração de uma 'rede', ao revés, pretende-se que exista articulação entre as ações particulares de cada serviço, o que somente ocorrerá quando houver uma produção assistencial que é minimamente partilhada pelos diferentes serviços, para o que há que ter definições institucionais que dialoguem entre si, serviços organizados em dinâmicas de atendimento que também, de algum modo, devem convergir para aspectos compartilhados dessa assistência, assim como há que se ter comunicação e interação entre os diversos profissionais envolvidos. (SCHRAIBER; PIRES; KISS, 2012, p. 236)

O sentido multifacetado que subjaz a essa atuação estatal em rede advém da visão de que o fenômeno da violência de gênero é complexo e permeado de significados que, necessariamente, perpassam pela atenção que se deve ter do agressor, como metodologia de proteção à mulher em situação de violência, categorizando-o como 
alvo das ações de prevenção previstas nas garantias consignadas na Lei 11.340/06.

Nosso mapeamento identificou que a trama de serviços atualmente existente termina por
envolver as seguintes atuações: orientação básica, policial, jurídica, assistência psicossocial,
saúde (englobando serviços médico-sanitários e de atenção psicológica) e abrigamento.
Além deles, para operar em rede, vamos incluir, então, os apoios da atuação
familiar/comunitária (SCHRAIBER; PIRES; KISS, 2012, p. 248)

a busca por elementos transdisciplinares que gravitam em torno da Lei Maria da Penha, busca-se aqui compreender em que ponto a decisão judicial, aqui tomada como elemento empírico do presente estudo, subestima as estratégias prescritas naquela norma, a exemplo da previsão de setores de prestação de serviços voltados ao agressor, sobretudo como forma de prevenir e erradicar a violência contra a mulher.

Portanto, não se perdendo de vista que o desfecho daquela história de violência doméstica foi a ocorrência de um feminicídio, seguido de suicídio, aqui, faz-se uso da perspectiva de Segato (2003), que ressalta as dinâmicas psíquicas e sociais presentes na violência de gênero, que não resultariam, necessariamente, de patologias individuais e tampouco são exclusivamente um "resultado automático da dominação masculina", mas do que a autora compreende como um sutil ciclo de reprodução das relações conflituosas de gênero, estruturante das relações pessoais e institucionais (SEGATO, 2013, p. 13)

\begin{abstract}
"Masculinidade" representa aqui uma identidade dependente de um status que engloba, sintetiza e confunde poder sexual, poder social e poder de morte. "Os homens", diz Ken Plummer em uma análise interessante das relações entre masculinidade e poder de violação, " se autodefinem a partir de sua cultura como as pessoas com necessidade de estar no controle, um processo que começa a aprender na primeira infância. Se este núcleo de controle desaparece ou se põe em dúvida, pode produzier-se uma reação a essa vulnerabilidade. [...] Esta crise no papel masculino pode ser a dinâmica central que se deve analisar para acessar as diferentes facetas da violação [...] os membros dos grupos sociais mais baixos parecem ser particularmente vulneráveis. Na classe operária trabalhadora e nas minorias raciais é que a crise atinge o seu pico: na parte inferior da escala social, seu senso de masculinidade é absolutamente fundamental" (Plummer, 1984, p. 49). Para o autor, "o problema da violação se torna em grande parte o problema da masculinidade, e é isso que deve ser investigado se se pretende resolver algum dia o primeiro" (ibid., p. 53). Isto significa entender exatamente o homem a quem me refiro neste trabalho, e os quadros de significado em que se entrelaçam masculinidade e o fenómeno da violação. (SEGATO, 2003, p. 37) $(\text { tradução nossa) })^{7}$
\end{abstract}

Neste propósito, convém destacar que, a assistência integral à mulher em situação de violência, a partir da

\footnotetext{
${ }^{7}$ Texto original: "Masculinidad" representa aquí una identidad dependiente de un estatus que engloba, sintetiza y confunde poder sexual, poder social y poder de muerte. "Los hombres", dice Ken Plummer en un interesante análisis de las relaciones entre masculinidad, poder y violación, "se autodefinen a partir de su cultura como personas con necesidad de estar en control, un proceso que comienzan a aprender en la primera infancia. Si este núcleo de control desaparece o se pone en duda, puede producirse una reacción a esa vulnerabilidad. [...] Esta crisis en el rol masculino puede ser la dinámica central que es preciso analizar para tener acceso a las distintas facetas de la violación [...] los membros de los grupos sociales más bajos parecen ser especialmente vulnerables. En la clase trabajadora y las minorías raciales esa crisis alcanza su máxima magnitud: en el fondo de la escala social, su sentido de la masculinidad es absolutamente fundamental" (Plummer, 1984, p. 49). Para este autor, "el problema de la violación se convierte, en gran medida, en el problema de la masculinidad, y es éste el que debe investigarse si se pretende resolver algún día el primero" (ibid., p. 53). Lo cual significa, justamente, comprender al hombre a quien aludo en este trabajo, y las tramas de sentido en las que se entrelazan la masculinidad y el fenómeno de la violación. (SEGATO, 2003, p. 37)
} 
ótica da percepção da figura do agressor, é trabalho que requer que se leve em conta as múltiplas perspectivas sobre as quais tal tema pode ser abordado.

Demanda-se a adoção de uma postura que possibilite com que o problema enfrentado seja tratado não só a partir de suas manifestações subjetivas evidenciadas, mas também no âmbito da inserção social e histórica dos sujeitos envolvidos: vítima, agressor e Estado.

De fato, é de se reconhecer que a postura do pesquisador, sobretudo quando problematiza um fenômeno multidimensional como este que ora se apresenta, demanda alguma coragem, em explorar o balizamento jurídico sobre o qual esta questão deve ser delineada e enfrentada.

A subsunção da violência praticada contra a mulher à Lei Maria da Penha desafia o magistrado a que este, nesta tarefa, ultrapasse a lógica jurídica formal como, por exemplo, aquela de enquadrá-la ao tipo penal correspondente e ainda à norma processual penal, conjugada às garantias de porte constitucional tais como aquelas decorrentes do princípio de não culpabilidade.

A manifestação dos fenômenos de violência perpetrada contra a mulher no ambiente doméstico deixa bastante claro que, levando-se em conta o ambiente e a conjuntura em que esta é praticada, deduzível é que a mesma se inicia a partir de uma situação de sujeição de gênero, um processo de subjugação que se instala, em muitos dos casos, a priori, pelo viés da violência psicológica, esta blindada pelo hermetismo de uma relação afetiva controladora, castradora, impulsiva e consequentemente, violenta.

Desta maneira, por exemplo, é sensitivo o fato de que, no contexto da violência de gênero, qual seja aquela perpetrada contra a mulher, a Lei Maria da Penha inaugura nova ótica sobre as prisões preventivas dos agressores domésticos, a ponto de que sua eventual revogação ultrapassa os critérios meramente formais, tais como as condições pessoais da primariedade, dos bons antecedentes e da residência fixa do agressor, que abrangem exclusivamente a eventual prática anterior de crimes sociais e não domésticos.

O agressor doméstico não necessariamente é um criminoso social contumaz, mas em geral o é em termos de ser violentador doméstico e/ou intrafamiliar, devendo estes antecedentes serem mais relevantes quando se está diante da condição de avaliar o risco potencial de um acusado de violência de gênero.

Assim sendo, a segurança da mulher, vítima de agressão, não deve estar submetida a critérios ordinários. De fato, aqui se trata de outra modalidade de periculosidade, qual seja aquela que assume um aspecto multiforme, refletido no campo das relações de afeto, que, necessariamente, requer o reconhecimento dos sujeitos que permitem visualizar as complexidades envolvidas nas ações tanto de quem a pratica, quanto de quem a sofre e de que modo isto tem implicância significativa nas políticas públicas relacionadas ao seu enfrentamento.

Eis que, observar um fato social sob esta perspectiva das subjetividades nele evidenciadas, demanda um reconhecimento de necessária relação de intersubjetividades (MACHADO, 2013, p. 48), um lançar-se num 
múltiplo espectro conceitual em que a regulação jurídica e sua linguagem hermética é, tão somente, um elemento a se considerar.

Desta feita, torna-se claro que a aplicação da Lei Maria da Penha requer que se ressignifique o Código de Processo Penal à sua luz e especificidade, afim de que este lhe sirva como instrumento hábil a abarcar o compromisso internacional de punir, prevenir e erradicar a violência contra a mulher:

O conflito social que está por trás da violência doméstica não pode ser tratado pura e simplesmente como matéria criminal. $\mathrm{O}$ retorno do rito ordinário do processo criminal para apuração dos casos de violência doméstica não leva em consideração a relação íntima existente entre vítima e acusado, não sopesa a pretensão da vítima nem mesmo seus sentimentos e necessidades. (CELMER; AZEVEDO, 2007)

Para o Judiciário, torna-se fundamental que o principio da igualdade, inscrito no texto constitucional, no que tangencia o fenômeno da violência doméstica, atenda às especificidades da Lei Maria da Penha e do contexto de violação aos direitos humanos que esta norma busca coibir e prevenir.

À guisa de exemplo, o Superior Tribunal de Justiça já firmou em precedentes, conforme se ilustra no Habeas Corpus n.o 123.804 - MG (2008/0276709-4), que:

"[...] condições pessoais favoráveis como primariedade, bons antecedentes e residência fixa no distrito da culpa, não têm o condão de, por si só, garantirem a revogação da prisão preventiva, se há nos autos elementos hábeis a recomendar a manutenção da custódia cautelar" (BRASIL, 2009).

O Superior Tribunal de Justiça firma entendimento de que a segregação cautelar do agressor, em sede da Lei Maria da Penha, além de servir para garantir a instrução criminal, deve ser também garantia da ordem pública quando se está diante da necessidade de preservação da integridade física e psicológica da vítima, de sua família e, ainda, como bem demonstrou o caso em análise, do próprio agressor.

Seguindo consulta ao sítio do Superior Tribunal de Justiça, lá se encontram precedentes que apontam para a necessidade da manutenção da custódia cautelar, que poderá ser decretada quando presentes os indícios do delito cometido, apoiado na prova da materialidade e na existência de indícios de autoria, e, ainda, o fato de que a liberdade do agente pode desestabilizar a ordem pública.

Ao que parece, esta conjuntura específica, ambientada no trato da norma especial, e a habilidade em manejá-la a favor da mulher submetida a situações de violência tem sido desprestigiada pela magistratura singular.

Quando A. C. C., respondendo por sequestro, cárcere privado e porte ilegal de armas, sob a guarda da Lei Maria da Penha, teve determinada sua soltura, mediante a revogação de sua prisão preventiva, tal fato se deu por decisão judicial que se construiu levando em conta elementos objetivos calçados no princípio da presunção da inocência (TRIBUNAL DE JUSTIÇA DO MARANHÃO, 2015), ignorando-se por completo a violência de gênero sobre a qual versava a situação criminosa em apreço e demais riscos adversos.

Percebe-se que na construção da ratio decidendi foram utilizados argumentos que se ampararam em uma lógica jurídica formal, hegemônica, adequada aos paradigmas tradicionais do processo penal quais sejam: o 
fato do então acusado possuir bons antecedentes, ter residência fixa e não haver provas concludentes de que o mesmo pudesse assumir atitudes que ameaçassem a coleta de provas.

Não se abordou a Lei 11.340/06 ou sequer se ventilou que o caso versava sobre violência de gênero, com isto tornando invisíveis todas as especificidades que permeiam o aludido fenômeno.

Ainda que a possibilidade de se decretar a prisão preventiva de um agressor no contexto da violência doméstica, com base na Lei Maria da Penha, requeira que se atendam aos pressupostos contidos no artigo 312 do Código de Processo Penal - e objetivamente, sob este viés, estes eram os argumentos que legitimariam a soltura de A. C. C., não fosse este agressor doméstico - o Judiciário, ao tomar tal espécie de decisão, deveria atentar para elementos outros, ligados à peculiaridade cíclica da violência de gênero, que, ao seu turno, dispensam um tratamento segundo um sistema processual penal generalista.

No caso em exame, a prisão cautelar do agente estaria calçada na conjunção da Lei Maria da Penha e sua função protetiva, associada ao inciso III, do artigo 313, do Código de Processo Penal, conjugado com o artigo 20, da Lei 11.340/06, a autorizá-la de maneira originária e autônoma.

O manejo da lei Maria da Penha, no propósito de se atender seu ideal de punir, prevenir e erradicar a violência contra a mulher, requer das instituições do sistema de justiça uma postura de compreensão transdisciplinar e uma ressignificação de sua postura ideológica no trato de seu alcance repressivo.

Trata-se de uma constante reflexão acerca de "como a Lei Maria da Penha atende aos tratados e convenções internacionais sobre direitos humanos, e sobre em que medida essa forma de ação do Judiciário contempla tais interesses (FREITAS, 2013)".

Resulta daí que a referida norma é resposta dada ao compromisso do Brasil no combate à violência contra a mulher, quando este $\mathrm{o}$ assume frente aos organismos internacionais que diligenciam na busca de oferecer mecanismos para o seu enfrentamento, diante dos quais é protagonista o Poder Judiciário. Vejamos:

A necessidade de assegurar a aplicação da lei penal não consiste somente em caso de iminência de fuga do distrito da culpa, mas também na própria credibilidade das instituições públicas imbuídas de prevenir e reprimir os delitos de violência doméstica contra a mulher, como, por exemplo, a Justiça. A lei protetiva, em seu artigo 20, também autoriza a prisão preventiva do agressor em qualquer fase do inquérito policial ou da instrução criminal. (VERAS, 20[?]).

Convém ao Judiciário, portanto, o reconhecimento da importância de seu papel frente à promoção da eficiência e credibilidade da Lei Maria da Penha, para que dela seja possível extrair todo o seu potencial de transformação social, no que tange ao atendimento da demanda relacionada à violência de gênero.

Para tanto, é necessário que seus agentes tomem posse dos significados constantes naquela norma, acerca do reconhecimento das diversas nuances de situações de agressão e vulnerabilidades pelas quais são submetidas as mulheres em situação de violência e a forma com que tais circunstâncias podem ser diluídas em posturas dogmáticas que não ratificam a integridade física e psíquica da mulher. 
A análise profícua dos termos da decisão que decretou a liberdade provisória de A. C. C. é capaz de demonstrar que a constatação de que não havia provas de que o agressor, então acusado, pudesse ameaçar a coleta de provas, a aplicação de possível pena, ou mesmo a paz social, evidentemente se deu sob uma perspectiva que lhe põe em questionável alheamento à realidade social da qual resultou a edição da Lei Maria da Penha e o fato de que esta demandaria uma ressignificação da lógica jurídica hegemônica.

É o que se extrai de seu texto que ora se transcreve:

Sendo assim, o CPP estabelece quais são as únicas hipóteses em que a prisão pode ser decretada. Desta feita, a imposição da preventiva reclama necessidade de garantir a ordem pública ou econômica, precisão de resguardar a instrução criminal ou possibilitar a aplicação da Lei Penal. Ademais, o juiz deve motivar o decreto de prisão, demonstrando as razões que o levaram a decidir e apontando os fatos em que o provimento se sustenta, sob pena de abuso de autoridade. Na questão que se examina, decretou-se a prisão do denunciado em face da periculosidade demonstrada pelas circunstâncias dos crimes praticados, capazes de pôr em risco a ordem e harmonia pública e afetar a credibilidade e a respeitabilidade do Poder Judiciário. (TRIBUNAL DE JUSTIÇA DO MARANHÃO, 2015)

À guisa de corroborar com esta constatação, observe-se que a ratio decidendi que se maneja para o trato deste problema social, baseado na violência de gênero, sequer faz menção da norma especial, destinada à sua abordagem judicial, mas cinge-se exclusivamente a uma investida meramente processual. Neste sentido, segue a decisão em análise:

Todavia, a mera gravidade do ilícito não é suficiente para fundamentar a cautelar, que deve sempre atender a uma necessidade do processo, no intuito de resguardar sua eficiência e, na questão, não há prova conclusiva de atitudes do acusado capazes de ameaçar a coleta da prova, a aplicação de possível pena ou mesmo a paz social. Como se vê, não sobram razões para autorizar a prisão, somente o peso dos crimes atribuídos, o que não justifica a cautela, sob pena de afronta ao princípio da presunção de inocência e ao devido processo legal, pois a preventiva não pode antecipar os efeitos de uma condenação transitada em julgado. $\mathrm{O}$ reconhecimento da relevância dos delitos não é suficiente para justificar a prisão preventiva do acusado, sob pena de se promover verdadeira e prematura imposição de pena, posto que, nesta hipótese, não se atende a qualquer necessidade atinente ao procedimento. (TRIBUNAL DE JUSTIÇA DO MARANHÃO, 2015)

O fato é que, para o deslinde da questão, optou o judiciário pelo caminho da imperícia, deixando de atentar, por desconhecimento, peculiaridades da questão social relacionada ao problema da violência de gênero, passando ao largo de um exercício interpretativo capaz de posicioná-lo no protagonismo das ações concernentes à Rede de Proteção à mulher em situação de violência.

Acerca dos problemas decorrentes da hipossuficiência técnica aqui diagnosticada, esta se emblematiza na própria concepção de garantia de ordem pública que a referida decisão acena para efeito de justificar a soltura do agressor, quando não a ressignifica dentro do contexto do fenômeno da violência de gênero:

Do ponto de vista da institucionalização do problema da violência contra a mulher, a Lei não apenas promoveu o reconhecimento formal da vulnerabilidade da mulher nas relações domésticas, familiares e afetivas, como também instituiu a força simbólica da pena na redefinição jurídica da violência como ato lesivo a valores e sentimentos coletivos, deslocando definitivamente o problema da esfera da vida privada para a esfera pública. 
(MACIEL, 2011)

Assim, evidencia-se a importância em se estudar o protagonismo do Judiciário na assistência integral à mulher em situação de violência, considerando aqui como ponto fulcral deste estudo, o tratamento dispensado ao agressor, necessariamente integrante de sua pena, ou ainda como componente importante da integralidade da assistência dada à própria vítima.

O que se explora é a utilidade de uma abordagem ressignificante, que permita uma atuação mais alargada no processo de enfrentamento das violências domésticas e de sua percepção, tanto na Política Nacional, quanto no Pacto Nacional de Enfrentamento à Violência Contra Mulheres, ultrapassando sua configuração estritamente criminalizadora.

Com efeito, sem a articulação de uma rede integrada que compatibilize os aspectos legais da Lei Maria da Penha, com ações de políticas públicas que efetivamente ponham em foco as ações que se inserem no Pacto Nacional de Enfrentamento à Violência Contra Mulheres, punir, prevenir e erradicar a violência de gênero tornase uma falácia.

Muito embora se considere que a previsão de articulação de serviços em rede, assim pronunciados para maior eficiência nas políticas públicas de enfrentamento represente um grande progresso, necessário é trilhar o caminho nem sempre fácil de encadeamento dessa rede a partir de uma mesma locução não dissonante:

Esses serviços fazem parte de dispositivos governamentais e não governamentais, e se distribuem em diversos setores de prestação de assistência, compondo um grande mosaico, mas ainda pouco inter-relacionado. Os estudos realizados sobre a oferta de cuidado pelos serviços criados especificamente para trabalhar com o problema da violência de gênero têm mostrado muitas dificuldades na operação dos princípios contidos nas Leis e políticas conquistadas. Os atendimentos são marcados por ambiguidades e contradições, os espaços e fluxos são inadequados à tarefa e a percepção dos profissionais é permeada, muitas vezes, por estereótipos acerca das relações de gênero, como mostra um estudo realizado em serviços de saúde e Delegacias de Defesa da Mulher22. Além disto, a lógica dos profissionais e suas expectativas quanto ao trabalho a ser realizado muitas vezes desconhece ou interpreta parcial ou equivocadamente as necessidades expressas pelas mulheres e as possibilidades de intervenção que elas almejam, criando obstáculos para a efetivação dos direitos em locais criados para garanti-los, como as Delegacias de Defesa da Mulher (D'OLIVEIRA; SCHRAIBER, 2013, p.137)

Assume-se a defesa da condição de não fazer uso do direito desconectado das múltiplas possibilidades de inserções transdisciplinares que circundam a magnitude e complexidade que caracterizam o fenômeno da violência contra a mulher, com foco na sua assistência integral.

\section{ALINHAVANDO UM CONCEITO DE ASSISTENCIA INTEGRAL}

A partir do que definem os artigos $1^{\circ}, 8^{\circ}$ e $9^{\circ}$, da Lei $11.340 / 06^{8}$, e do entendimento pelo qual se

${ }^{8}$ Art. $1^{\circ}$. Esta Lei cria mecanismos para coibir e prevenir a violência doméstica e familiar contra a mulher, nos termos do $\$ 80$ do art. 226 da Constituição Federal, da Convenção sobre a Eliminação de Todas as Formas de Violência contra a Mulher, da Convenção 
compreende o direito como o produto cultural de uma escalada histórica do gênero humano e de suas relações mútuas, assinala-se que a inserção da assistência integral na norma resulta de múltiplas dimensões dadas aos direitos da mulher em situação de violência, como reconhecimento de um direito humano pela proteção à sua integridade física e psicológica.

Surge assim no cenário legislativo nacional a Lei Maria da Penha, como um estatuto que resulta de ações que se deram, tanto em um panorama nacional quanto internacional, com fito de firmar uma ideologia de igualdade de gêneros e que, por outro lado, materializou a força normativa outrora limitada e programática do que se acha contido no artigo 226, $\$ 8^{\circ}$ da Constituição Federal ${ }^{9}$.

A perspectiva de assistência integral no trato da violência contra a mulher se revela na mobilização de processos conexos que não restrinjam o trato da violência contra a mulher a práticas unicamente criminalizantes, polarizando vítima e agressor, numa base ortodoxa de litigiosidade.

Lilia Guimarães Pougy propõe um exercício de aplicação da “oposição dialética”, pela qual busca a autora envolver os sujeitos submergidos em uma situação de violência doméstica, a partir de um movimento pelo qual "homens e mulheres poderiam ser transformados após a punição dos atos criminosos", para tanto, opinando ser a intervenção interdisciplinar fundamental, pela qual "as diferentes disciplinas e profissões distintas poderiam reunir subsídios à construção de metodologias inovadoras", reconhecidas pelos sistemas de segurança e justiça e demais personagens que atuam no campo de enfrentamento das violências fundadas em relação de poder baseada no gênero (POUGY, 2010, s/p).

Percebe-se a necessidade de se compreender esta problemática na eficiência de sua feição já judicializada, e em que medida o Judiciário, como instituição do sistema de justiça, mantem-se atento e dialoga com o que consiste a verdadeira natureza da Lei Maria da Penha, como aquela que não se limita ao recrudescimento no

Interamericana para Prevenir, Punir e Erradicar a Violência contra a Mulher e de outros tratados internacionais ratificados pela República Federativa do Brasil; dispõe sobre a criação dos Juizados de Violência Doméstica e Familiar contra a Mulher; e estabelece medidas de assistência e proteção às mulheres em situação de violência doméstica e familiar.

(...)

Art. $8^{\circ}$. A política pública que visa coibir a violência doméstica e familiar contra a mulher far-se-á por meio de um conjunto articulado de ações da União, dos Estados, do Distrito Federal e dos Municípios e de ações não-governamentais, tendo por diretrizes:

I - a integração operacional do Poder Judiciário, do Ministério Público e da Defensoria Pública com as áreas de segurança pública, assistência social, saúde, educação, trabalho e habitação;

(...)

Art. 9. A assistência à mulher em situação de violência doméstica e familiar será prestada de forma articulada e conforme os princípios e as diretrizes previstos na Lei Orgânica da Assistência Social, no Sistema Único de Saúde, no Sistema Único de Segurança Pública, entre outras normas e políticas públicas de proteção, e emergencialmente quando for o caso.

$\$ 1$ O juiz determinará, por prazo certo, a inclusão da mulher em situação de violência doméstica e familiar no cadastro de programas assistenciais do governo federal, estadual e municipal. (BRASIL, 2006)

${ }^{9}$ Art. $226(.$.

\ $8^{\circ} \mathrm{O}$ Estado assegurará a assistência à família na pessoa de cada um dos que a integram, criando mecanismos para coibir a violência no âmbito de suas relações. (BRASIL, 1988) 
tratamento criminal das situações de violência lá previstas, mas traduz-se em proposta de uma macroestrutura de intervenção:

Em muitas situações a mulher acaba sendo revitimizada, considerada fraca, irresponsável, provocadora e resistente às funções e aos papéis sociais destinados ao seu gênero e classe. $\mathrm{O}$ grande desafio que se coloca é a instauração de práticas interdisciplinares, nas quais a intervenção seja orgânica ao projeto da sociedade que se deseja, situação possível com base na elaboração e desenvolvimento de um plano teórico-político consistente. As bases estão dadas com a larga experiência no campo do enfrentamento da violência contra a mulher e também previstas no texto da Lei Maria da Penha, especialmente nos Art. 9 e 29, "Da assistência à mulher em situação de violência doméstica" e "Da equipe de atendimento multidisciplinar". (POUGY, 2010)

Decerto que, quando A. C. C. foi preso em flagrante por ter sequestrado a ex-namorada M. N. S. S, mantendo-a em cárcere privado sob a mira de uma arma, a posterior revogação de sua prisão se deu mediante clara exigência de não se afastar do domicílio de seu irmão, segundo retrata o caso, sem comunicação prévia ao juízo criminal, bem como comprovar nos autos o início de terapêutica médica para tratamento de depressão, tudo conforme o que se depreende da decisão que determinou sua soltura e da justificativa contida em pronunciamento da Associação dos Magistrados.

Naquele caso, a soltura do agressor se deu num modelo pragmático, em conformidade com o artigo 312 do Código de Processo Penal, dispositivo de certa forma albergado pela Lei 11.340/06.

Contudo, cabe refletir que, à luz deste estatuto de proteção à mulher em situação de violência, o Poder Judiciário deve estar atento a variáveis que especializam o trato punitivo da violência doméstica, sobretudo a sua natureza cíclica e muito peculiar.

Estudos feitos pela Secretaria Especial de Políticas para as Mulheres (SEMP) constataram que a situação de violência, muitas vezes, é cíclica, pois as vítimas encontram diversos obstáculos na busca de proteção e reparo, resultando em desgaste emocional e retorno à posição de vítima. A falta de medidas protetoras disponíveis para a mulher agredida, assim como a falta de atenção para a gravidade do problema, geralmente, produzem resultados drásticos, ficando evidente a falta de atenção da esfera responsável por esse serviço, possibilitando que a vítima retorne à situação de violência por não encontrar alternativa. (PARENTE; NASCIMENTO; VIEIRA, 2009, p. 457)

É factível que a técnica equivocada, porque negligente daquela peculiaridade, no âmbito da assistência integral por parte do Judiciário, bem como das ações governamentais, poderá comprometer sobremaneira seu fortalecimento por parte das instituições a quem cabe o enfrentamento destas questões relacionadas à violência de gênero.

Por conseguinte, a postura negligente, no manejo da Lei Maria da Penha, no ponto em que esta toca o Serviço de Responsabilização e Educação do Agressor da Rede de Atendimento e de Enfrentamento à Violência contra as Mulheres é capaz de provocar a não integralidade de atenção às mulheres submetidas à situação de violência.

Há que se entender o tratamento e/ou reeducação do agressor como integralizando o atendimento à 
vítima, bem como podendo, inclusive, integrar as ações penalizadoras, repressivas do Estado, uma vez que, em um primeiro momento, este atendimento será, ou deveria ser, imposto pelo próprio Estado, mediante a articulação de tratamento psicológico a que deveria ser submetido o réu, este a ser articulado junto à esfera pública municipal.

\section{INVISIBILIDADE DAS ESPECIFICIDADES DOS AGRESSORES DOMÉSTICOS}

Quando A. C. C. teve decretada sua soltura, noticia a instituição representativa da magistratura que esta havia se dado em razão de que, legalmente, o mesmo reunia todas as condições processuais para a adoção desta medida: era primário, tinha bons antecedentes, endereço fixo e, ademais, necessitava se submeter a tratamento para depressão.

À luz da norma processual penal hegemônica, mantê-lo preso seria uma incoerência ante estas evidências materiais, até porque a própria vítima assim o solicitara, concordando com seu livramento, conforme fartamente noticiou a imprensa (JORNAL O IMPARCIAL, 2015, s/p).

O que ocorreu em seguida está creditado à mera fatalidade, à ausência de um aparato estatal ou à imperícia dos operadores do direito na compreensão do fenômeno da violência doméstica?

A. C. C. precisava se submeter a um tratamento para depressão. A. C. C. manteve M. N. S. S. em cárcere privado. A. C. C. seria posto em liberdade para buscar, voluntariamente, este tratamento. Com a palavra, a Lei Maria da Penha:

Art. 29. Os Juizados de Violência Doméstica e Familiar contra a Mulher que vierem a ser criados poderão contar com uma equipe de atendimento multidisciplinar, a ser integrada por profissionais especializados nas áreas psicossocial, jurídica e de saúde.

Art. 30. Compete à equipe de atendimento multidisciplinar, entre outras atribuições que the forem reservadas pela legislação local, fornecer subsídios por escrito ao juiz, ao Ministério Público e à Defensoria Pública, mediante laudos ou verbalmente em audiência, e desenvolver trabalhos de orientação, encaminhamento, prevenção e outras medidas, voltados para a ofendida, o agressor e os familiares, com especial atenção às crianças e aos adolescentes.

Art. 31. Quando a complexidade do caso exigir avaliação mais aprofundada, o juiz poderá determinar a manifestação de profissional especializado, mediante a indicação da equipe de atendimento multidisciplinar.

(...)

Art. 35. A União, o Distrito Federal, os Estados e os Municípios poderão criar e promover, no limite das respectivas competências:

I - centros de atendimento integral e multidisciplinar para mulheres e respectivos dependentes em situação de violência doméstica e familiar;

II - casas-abrigos para mulheres e respectivos dependentes menores em situação de violência doméstica e familiar;

III - delegacias, núcleos de defensoria pública, serviços de saúde e centros de perícia médicolegal especializados no atendimento à mulher em situação de violência doméstica e familiar; IV - programas e campanhas de enfrentamento da violência doméstica e familiar;

V - centros de educação e de reabilitação para os agressores. (BRASIL, 2006)

Não há notícias de qualquer menção na decisão em análise, dos dispositivos acima transcritos para efeito 
de condução da situação de risco pela qual passaria M. N. S. S., em razão da soltura de seu algoz, muito embora existam, tanto no âmbito municipal, quanto no âmbito estadual, políticas de gênero implementadoras de ações voltadas para mulheres em situação de violência. A respeito destas prerrogativas legais, a decisão ora analisada não fez qualquer menção aos serviços disponibilizados pela Secretaria Municipal de Políticas para as Mulheres de Pedreiras ${ }^{10}$.

Sobram daí duas evidências a seguir: a primeira, e de característica mais abrangente, é a de que, muito embora a Lei Maria da Penha, por si só, representa grande avanço no tratamento legal das garantias de proteção aos direitos da mulher, em termos de quantificação das demandas relacionadas à violência de gênero, no eixo repressivo de sua expressão legal, por outro lado, a condução de seus mecanismos de proteção tropeça em posturas interpretativas desqualificadoras de seu potencial protetivo.

A segunda, mais particularmente em relação ao caso em análise, revela a constatação de que falta à magistratura perícia para decidir sobre a violência doméstica contra a mulher, quando, ao decretar a soltura do agressor doméstico - nos moldes em que se deu a decretação da liberdade provisória de A. C. C. - deixa de atentar para o fato de que não se está diante de uma violência social comum.

Pelo contrário, a decisão revela a fragilidade da percepção da gravidade da violência praticada no ambiente doméstico ou nas relações de afeto, e da necessidade sobrepujante de sua punição e prevenção, expressada indubitavelmente pela própria Lei Maria da Penha e pelos movimentos sociais de lutas emancipatórias que gravitam em torno de sua edição, cuja importância, conteúdo e alcance não podem ser desqualificados ou mesmo ignorados, por quem tem o papel fundamental de julgar o agressor e proteger a vítima:

Não há dúvidas de que a Lei Maria da Penha está provocando deslocamentos discursivos que afirmam cada vez mais os direitos das mulheres relacionados a uma vida livre de violência, rompendo com a ordem de gênero do direito penal. No entanto, as resistências à aplicação da Lei, embora cada vez mais reduzidas, buscam frear esse novo posicionamento. As tensões entre o conservadorismo legal (doutrinário e jurisprudencial) e as propostas feministas devem ser resolvidas na superação do primeiro e na inscrição de um novo lugar para as mulheres, a partir do segundo. (CAMPOS, 2014)

Norbert Rouland (ROULAND, 2018, p. 259-263), ao defender uma visão antropológica do direito e

\footnotetext{
${ }^{10}$ O Município de Pedreiras, através da Secretaria Municipal de Políticas para as Mulheres de Pedreiras, criada pela Lei municipal no 1353/2013 e vinculada ao poder executivo, com estrutura organizacional e dotação orçamentária própria, mediante assessoramento técnico realizado pela Secretaria de Estado da Mulher, através do projeto "fortalecendo as políticas de gênero nos municípios maranhenses: estadualização do plano nacional de políticas para as mulheres”, elaborou o Plano Municipal de Políticas para as Mulheres - Plano Plurianual 2014-2017. Fomentado em diagnósticos e propostas através de reuniões, com organismos públicos governamentais e não governamentais, sob os princípios que norteiam as Diretrizes da Política Nacional para as Mulheres o referido Plano, dentre outras prioridades, assumiu o controle social de gestão de políticas afirmativas de gêneros, mediante aprovação do Conselho Municipal da Mulher (CMPM de Lei no 1.273/09-09-2009) tendo por base o enfrentamento à violência de todas as formas contra as mulheres. Dentre as ações relativas àquele objetivo, destaca-se o acompanhamento psicossocial de mulheres vítimas de violência através do PAEFI (Serviço de Atendimento Especializado de Proteção à Família), cuja meta foi a inclusão de $80 \%$ das mulheres vítimas de violência anualmente, sob a responsabilidade Secretaria Municipal de Políticas para as Mulheres de Pedreiras. (BRASIL, Maranhão. Pedreiras. 2014, s/p)
} 
reconhecer a sociedade civil como sua fonte, afirma a necessidade de superação de uma visão tradicional do Estado de Direito, que se esgota diante do monismo jurídico e propõe uma teoria pluralista que melhor explica a limitação do Estado, não pelo Direito, mas pelos direitos. sob pena de que aquela visão monista torne o Estado de Direito uma ilusão.

Esta concepção nasce da percepção de que, muito embora nas sociedades modernas vigorem valores incompatíveis com a busca do consenso (tais como o individualismo, a competição, maior densidade social e demográfica, crescente polarização geradora de conflitos, aumento de tamanho das unidades sociais a requererem o julgamento por um direito imperativo, normatizado, hegemônico, fruto de uma atividade legislativa), a concretude de seus litígios, em países periféricos como o Brasil, quando deparados com a norma abstrata, encontra um fosso, cuja travessia demanda que se aguce nosso senso de justiça, ante a ineficácia de nos fiarmos em um sistema jurídico amparado só em normas.

Faz-se necessário que os operadores do direito se permitam uma reflexão mais ampla no que tange à abordagem legal dada às mais diversas situações postas, quando demandado o manejo da Lei Maria da Penha, para que este Estatuto alcance a necessária intervenção em que se requer uma expertise institucional acerca do fenômeno da violência e do que dele resulta em termos de: choque, negação, recolhimento, confusão, entorpecimento, medo, depressão, desesperança, baixa autoestima e negação, num "resquício permanente da sujeição psicológica do passado" que em geral acometem vítima e agressor doméstico (MACHADO, 213, p. 96).

Neste ponto, torna-se oportuno comparar a ideia ora aqui trabalhada, nos limites deste trabalho, e no que tange à percepção disfuncional do judiciário da figura do agressor e de que modo isto corrobora para um subaproveitamento das garantias consignadas na Lei 11.340/06, com os achados constantes no relatório de pesquisa institucional referente aos casos denunciados na Vara Especial de Violência Doméstica e Familiar contra a Mulher, de São Luís, Maranhão, no ano de 2014 (BRASIL, 2015).

Segundo informações disponibilizadas naquele documento, foram identificados 414 processos de Medidas Protetivas de Urgência (MPU's), entre ativos e arquivados, distribuídos nos meses de janeiro a abril de 2014.

De acordo com os dados expostos no relatório, quanto aos tipos de violência praticados, lá se observa a amostra de um percentual de 29,2\% de violência moral e 34,4\% de violência psicológica, ou seja, a mulher tem provocado o exercício jurisdicional daquela especializada, em situações cuja sua grande maioria são aquelas relacionadas à violência psicológica, seja ela assim diagnosticada pelo cometimento das agressões morais - tais como a injúria, a ameaça, a coação ilegal, ou outras formas de assédio -, seja ela na sua forma pura, o que não fica exatamente claro no documento consultado.

Com relação aos demais tipos de agressão, lá se verifica um percentual de $24 \%$ de violência física; $11,2 \%$ 
de violência patrimonial e $1,2 \%$ de violência sexual.

Pontue-se que a amostra colhida faz considerar que a provocação do judiciário se dá, massivamente, em situações de violência psicológica já consolidada e, inclusive, vinculada ao cometimento de outras espécies de agressão praticada contra a mulher, pelo que cabe aqui uma reflexão acerca da importância da definição do conceito de violência psicológica no que tange a um enfrentamento global e preventivo desta modalidade de violência, o que, necessariamente passa pela a construção de políticas que se articulem com uma eficaz anamnese do agressor, a fim de que ações punitivas mais eficientes e ações preventivas sejam implementadas, a ponto de possibilitar uma reconstrução das subjetividades envolvidas no fenômeno da violência doméstica.

Assim, vê-se que a compreensão da gravidade da violência praticada no âmbito das relações doméstica e familiar, possibilita o enfrentamento de um problema social cujo reconhecimento e apreensão requerem ações e punições transdisciplinares a fim de que se possa oferecer um atendimento efetivamente integral à vítima.

Por em liberdade A. C. C., em respeito ao princípio constitucional de presunção de sua inocência, sobretudo ante o motivo de que precisava o mesmo se submeter a um tratamento para depressão, reivindica, por parte do Estado, a conjunção de fatores que, necessariamente, corroborariam com seu papel de promotor da justiça e da paz social.

Trata-se da responsabilidade de fazê-lo atento, obrigatoriamente, a um suporte que assim assegurasse ao acusado a sua eficaz custódia enquanto tramitava a persecutio criminis, resguardando-lhe sua própria incolumidade, face à constatação de seu estado de saúde mental. Por outro lado, pô-lo em liberdade, de igual forma, demandaria, também por parte do Estado, o resguardo de que, minimamente, não viesse M. N. S. S. a ser revitimizada pela ausência ou mesmo pela inoperância ou negligência quanto ao seu encaminhamento a uma estrutura de apoio que lhe pudesse garantir sua própria segurança.

Decorre daí que o papel do magistrado é extrair da lei Maria da Penha seu potencial humanístico, o que, necessariamente passa por reconhecer a vulnerabilidade específica da vítima daquela espécie de violência, bem como a caracterização do ciclo em que a mesma é deflagrada.

Ao se analisar a decisão que permitiu com que A. C. C. fosse posto em liberdade, é possível notar a sua falta de referência à legislação que necessariamente deveria sustentá-la, qual seja, a Lei Maria da Penha, fato que revela por parte do Judiciário uma visão perigosamente condescendente para com o agressor doméstico, assim classificando-o sob uma ótica de comportamento padrão, cujas especificidades não ultrapassam a superficial avaliação de sua primariedade e seus bons antecedentes.

Com efeito, o Brasil, na condição de signatário de tratados e convenções internacionais de direitos humanos, editou a Lei 11.340/06 para atender a reclames de ordem externa, a fim de que se mobilizasse formalmente no que tange ao combate à violência de gênero, não só no sentido de oferecer normas jurídicas mais 
robustas quanto à punição destas práticas, mas também institucionalizasse políticas voltadas à garantia dos direitos das mulheres.

Boaventura de Sousa Santos denomina de "curto-circuito histórico (SANTOS, 2007, p. 26)" a consagração de direitos em países periféricos, caso do Brasil, mediante a constitucionalização de um extenso conjunto de garantias, num mesmo ato institucional - por exemplo, a própria Lei 11.340/06, como norma que atende a um comando-valor de estatura Constitucional, qual seja aquele previsto no artigo 226, $\$ 8^{\circ}$ da Constituição Federal -, sem a correspondência de um processo histórico de conquistas, o que poderia explicar o hiato assim diagnosticado no fato de que tais direitos não se acham respaldados por políticas públicas e sociais, fundamentalmente consolidadas que os garantam, o que acaba fazendo com o que o Judiciário se transforme numa instância reprodutora de desigualdades.

Por outro lado, esta realidade reclama do Poder Judiciário um protagonismo frente à efetividade da Lei Maria da Penha e sua função protetiva que, necessariamente, requer do julgador uma profunda intimidade com os dispositivos daquela norma, fato que resultaria na qualidade da percepção da violência praticada contra as mulheres e as peculiaridades de seu cenário: no caso um homem incomodado com o fim de um relacionamento deve encontrar no Judiciário uma eficiente contenção para sua agressividade já manifestada.

As estatísticas demandam ${ }^{11}$ que, no enfrentamento da violência contra a mulher, a magistratura ressignifique sua compreensão deste fenômeno, no sentido de que esta não deve atender às suas convicções pessoais, internalizadas seja por uma ótica patriarcalista, seja por uma lógica jurídico-formal da norma penal, para capacitar-se no manejo da Lei Maria da Penha.

Naquela citada obra o autor questiona "que tipo de mobilização política pode ser feita para sustentar uma mobilização jurídica de aprofundamento democrático" (SANTOS, 2007, p. 39), para tanto reconhecendo a existência de fraturas que inviabilizam novas concepções de independência judicial, e que conformam uma justiça rotinizada.

Porquanto esteja protegida a decisão que pôs em liberdade A. C. C. pelo escudo da legalidade, contra a qual não há ressalvas, sob o ponto de vista da dogmática processual penal, tem-se que a mesma é sintomática em demonstrar não haver emancipação do Judiciário em adotar uma autonomia decisória que resguarde o potencial protetivo da lei Maria da Penha, tanto em relação à vítima, quanto em relação ao próprio agressor. É certo que esta autonomia, necessariamente demanda qualificação e expertise da magistratura, bem como um anteparo estatal efetivamente eficiente.

\footnotetext{
${ }^{11}$ Dos 4.762 homicídios de mulheres registrados em 2013 pelo SIM [Sistema de Informações de Mortalidade], 2.394, isso é, 50,3\% do total nesse ano, foram perpetrados por um familiar da vítima. Isso representa perto de 7 feminicídios diários nesse ano, cujo autor foi um familiar. 1.583 dessas mulheres foram mortas pelo parceiro ou ex-parceiro, o que representa $33,2 \%$ do total de homicídios femininos nesse ano. Nesse caso, as mortes diárias foram 4. (WAISELFISZ, 2015, p. 70)
} 
A Política Nacional de Enfrentamento à Violência Contra as Mulheres estabelece conceitos, princípios, diretrizes e ações de prevenção e combate à violência contra as mulheres e, ainda, define a assistência e garantia de direitos às mulheres em situação de violência, estruturada a partir do Plano Nacional de Políticas para as Mulheres, que assim conceitua a Rede de Enfrentamento à Violência Contra a Mulher (BRASIL, 2011b):

A rede de enfrentamento corresponde à atuação articulada entre as instituições/serviços governamentais, não-governamentais e a comunidade, com o objetivo de desenvolver estratégias de prevenção e de políticas que garantam o empoderamento das mulheres e seus direitos humanos, a responsabilização dos agressores e a assistência qualificada às mulheres em situação de violência. Já a rede de atendimento é formada por um conjunto de ações e serviços de diferentes setores (em especial, da assistência social, da justiça, da segurança pública e da saúde), que visam à ampliação e à melhoria da qualidade do atendimento; à identificação e aos encaminhamentos adequados das mulheres em situação de violência.

Nesta rede de atendimento, marcada pela multiplicidade de serviços e instituições, dela constitui parte o Serviço de Responsabilização e Educação do Agressor da Rede de Atendimento e de Enfrentamento à Violência contra as Mulheres, cuja função será a de, obrigatoriamente, atuar de forma articulada com os demais serviços da rede (Juizados de Violência Doméstica e Familiar contra a Mulher, promotorias especializadas, Casas-Abrigo, Centro de Referência da Mulher, Delegacias Especializadas de Atendimento à Mulher, Defensorias/Núcleos Especializados da Mulher, Centros de Referência Especializados de Assistência Social, serviços de saúde, etc.), assim contribuindo para a prevenção e o combate à violência contra as mulheres nos seguintes moldes:

O Serviço de Responsabilização e Educação do Agressor é responsável pelo acompanhamento das penas e das decisões proferidas pelo juízo competente no que tange aos agressores, conforme previsto na Lei 11.340/2006 e na Lei de Execução Penal. Esses serviços deverão, portanto, ser vinculados aos tribunais de justiça estaduais e do Distrito Federal ou ao executivo estadual e municipal (Secretarias de Justiça ou órgão responsável pela administração penitenciária). (BRASIL, 2011a)

No caso do Maranhão, o Estado conta com a Rede Estadual de Atendimento às Mulheres em Situação de Violência, cuja carta de serviços, elaborada pelo Departamento de Monitoramento e Avaliação da Secretaria de Estado da Mulher, descreve e mapeia os serviços que compõem a Rede Estadual de Atendimento às Mulheres em Situação de Violência do Maranhão, dentre eles destaque-se a articulação para desenvolvimento de ações pelo Programa Viva Mulher (Secretarias Estadual e Municipais de Saúde, INSS, SEDES, SETRES, SSP, SEDIHC, MPE), com criação de grupos de trabalho para atender as diversas demandas da secretaria (comissões internas) (BRASIL. Maranhão, 2014b, s/p).

Há ainda, no âmbito estadual, a realização de diálogos com a rede de serviços de atendimento à mulher para fortalecimento do enfrentamento à violência contra as mulheres, cuja finalidade é "a Pactuação fundamental para o enfrentamento à violência contra as mulheres no Maranhão", bem como "estabelecer e fortalecer parcerias da SEMU com outros órgãos, bem como a criação de organismos de Políticas para as Mulheres-OPMs" (BRASIL. Maranhão, 2014c, s/p).

Segundo a decisão que determinou a soltura de A. C. C., revogando-lhe a prisão preventiva 
(TRIBUNAL DE JUSTIÇA DO MARANHÃO, 2015), datada de 04 de agosto de 2015, fê-lo o Judiciário condicionando-a a que o acusado juntasse aos autos do processo comprovante de início de tratamento médico em 10 dias. Sucede que não há referência de qualquer engenharia institucional no sentido de conjugar tarefas para promoção e acompanhamento do referido tratamento e o alcance da coercibilidade de tal decisão, numa perspectiva de atuação conjunta dos atores inseridos na rede de atendimento.

Fica a seguinte reflexão: ou o Judiciário os desconhece, ou mesmo os subestima, a eles e às políticas públicas na Lei previstas para atuarem em uníssono com os demais atores da rede. Cumpre destacar que ambas as possibilidades podem ainda estar sedimentadas na hipossuficiência técnica em relação à especificidade da violência de gênero em modalidade doméstica e ou intrafamiliar.

Conquanto, o que se noticiou nos autos do processo, não foi o início do tratamento do acusado, mas o assassinato M. N. S. S., seguido do suicídio de A. C. C., fato trágico que ganhou ampla divulgação na imprensa, expondo as fragilidades das instituições do sistema de segurança e justiça no que diz respeito ao manejo da Lei Maria da Penha para além de seu aspecto repressivo.

Boaventura de Sousa Santos, em sua já citada obra, Para uma Revolução Democrática da Justiça, discute a ausência de empoderamento do judiciário, quando percebe a falta de autonomia decisória presente na cultura jurídica dominante e, para tanto, vale-se da alegoria de um o "retrato-robot do magistrado ${ }^{12}$ " que utiliza para desenhar o perfil da magistratura no Brasil.

O que Santos utiliza eficazmente para traçar o retrato-robot do juiz, como elementos que caracterizam uma cultura normativista, técnico-burocrata, socorre as intenções deste trabalho quando aqui se busca argumentar acerca da percepção disfuncional do judiciário da figura do agressor e de que modo isto corrobora para um subaproveitamento das garantias consignadas na Lei 11.340/06, assim conformando obstáculos para a eficácia de ações que pudessem impedir atos de violência como o de A. C. C.

Caracteriza o autor neste retrato (SANTOS, 2007, p. 84-86) um judiciário que prioriza o direito civil e o direito penal, segundo a tradição da dogmática jurídica que autoriza com que tais ramos do direito sejam aplicados autonomamente, de forma dissociada de um conhecimento transdisciplinar.

Afirma também a característica de que "só o magistrado, por ser magistrado, tem a competência para resolver litígios, e de que, pela mesma razão, tem competência para resolver todos os litígios" (SANTOS, 2007, p. 84).

Assim, não fosse o processo penal a única variável utilizada para equacionar a revogação da prisão preventiva de A. C. C., tivesse o Judiciário desapegado do "privilégio do poder", valendo-se de uma atuação não

\footnotetext{
12 "Ao desenhá-lo, certamente vou cometer injustiça contra muitos magistrados. Trata-se, contudo, apenas de um retrato-robot que, naturalmente, não tem que retratar todas as situações gerais. E de maneira nenhuma retrata situações particulares." (SANTOS, 2007.p. 83)
} 
autoritária e multidisciplinar, pode-se pensar, ou mesmo nutrir a esperança que, talvez, outra seria a condução de sua responsabilidade sobre a custódia do réu e, por conseguinte, outro seria o destino de M. N. S. S.

Chama-nos a atenção, Santos (2007), para o fato de que, neste sentido, o Judiciário finda por confundir independência com autossuficiência, ou seja, trata-se da constatação de que, na condução dos processos com vistas à realização da justiça, não há no magistrado brasileiro uma cultura de trabalho de equipe, o que torna possível observar "uma oposição militante à colaboração interdisciplinar e uma ideia de autossuficiência que não permite aprender com outros saberes" (SANTOS, 2007, p. 86).

Aponta ainda o autor, como manifestação desta cultura, o que ele chama de "refúgio burocrático" (SANTOS, 2007, p. 85), afirmando ser:

A preferência por tudo o que é institucional, burocraticamente formatado. São os seguintes os sintomas mais evidentes desta manifestação: uma gestão burocrática dos processos, privilegiando-se a circulação à decisão - o chamado andamento aparente dos processos; a preferência por decisões processuais, em detrimento de decisões substantivas; a aversão a medidas alternativas, por exemplo, penas alternativas, por não estarem formatadas burocraticamente.

Ainda caracterizando os elementos desta chamada cultura normativista, técnico-burocrata, Santos adverte que o Judiciário está longe da sociedade. O Juiz possui a expertise para interpretar o direito, mas não comunga desta excelência para interpretar a realidade:

Conhece bem o direito e a sua relação com os autos, mas não conhece a relação dos autos com a realidade. Não sabem espremer os processos até que eles destilem a sociedade, as violações de direitos humanos, a pessoas a sofrerem, as vidas injustiçadas. Como interpreta mal a realidade, o magistrado é presa fácil de ideias dominantes. Aliais, segundo a cultura dominante, o magistrado não deve ter sequer ideias próprias, deve é aplicar a lei. [...] É aí que se cria um senso comum muito restrito a partir do qual se analisa a realidade. Este senso comum é enviesado pela suposta cientificidade do direito que, ao contribuir para sua despolitização, cria a ficção de uma prática jurídica pura e descomprometida. (SANTOS, 2007, p. 85-86).

Vejamos na situação posta acerca da condução do caso de M. N. S. S, de que maneira o Fórum Nacional de Juízes de Violência Doméstica e Familiar contra a Mulher ${ }^{13}$ instrui, quanto à articulação da rede de atendimento à mulher em situação de violência, ao se buscar a compreensão da complexidade da violência contra as mulheres e do caráter multidimensional do problema:

ENUNCIADO 13 - Poderá a Equipe Multidisciplinar do Juízo proceder ao encaminhamento da vítima, do agressor e do núcleo familiar e doméstico envolvido à rede de atenção integral, independentemente de decisão judicial.

ENUNCIADO 14 - Os Tribunais de Justiça deverão prover, obrigatoriamente, os Juízos com competência para processar e julgar os processos de violência doméstica e familiar contra a mulher, de Equipe Multidisciplinar exclusiva, com quantidade de profissionais dimensionadas de acordo com o manual de rotinas estruturação de Juizados de Violência

\footnotetext{
${ }^{13} \mathrm{O}$ Fórum, que congrega magistrados de todos os Estados brasileiros e do Distrito Federal envolvidos com a temática de violência de gênero, tem como objetivo propiciar a discussão das questões relacionadas à aplicabilidade da Lei 11.340/2006, buscando o compartilhamento de posicionamentos e experiências e a compreensão, com profundidade, dos aspectos jurídicos da legislação e também dos contornos que envolvem outras disciplinas relacionadas. (FONAVID, s/d)
} 
Doméstica e Familiar contra a Mulher do CNJ.

ENUNCIADO 16 - Constitui atribuição da Equipe Multidisciplinar conhecer e contribuir com a articulação, mobilização e fortalecimento da rede de serviços de atenção às mulheres, homens, crianças e adolescentes envolvidos nos processos que versam sobre violência doméstica e familiar contra a mulher.

ENUNCIADO 26 - O juiz, a título de medida protetiva de urgência, poderá determinar o comparecimento obrigatório do agressor para atendimento psicossocial e pedagógico, como prática de enfrentamento à violência doméstica e familiar contra a mulher. (Aprovado no IV Fonavid). (BRASIL, 2014)

Por esta razão, reconhece-se que o potencial protetivo da Lei Maria da Penha demanda, necessariamente, que o Judiciário assuma o papel de catalizador das políticas que ofereçam resposta eficaz no atendimento daquela demanda.

A atuação pontual e dissociada do magistrado, alheio ao suporte das garantias consignadas na Lei 11.340/06, e nas concepções que gravitam em seu entorno, sejam elas provenientes dos entes estatais, sejam elas pontuadas pela academia, decerto, tem demandado uma resposta eficaz no enfrentamento dos crimes de violência doméstica e familiar cometidos contra a mulher.

\section{CONSIDERAÇÕES FINAIS}

Portanto, buscando examinar a percepção disfuncional do Judiciário da figura do agressor, e de que modo isto corrobora para um subaproveitamento das garantias consignadas na Lei 11.340/06, tanto no aspecto jurídico-legal, quanto no aspecto sócio-antropológico e ainda problematizando a valorização da integridade da vítima, a partir de ações preventivas que resguardem sua incolumidade, percebeu-se, em primeira mão, a importância das Redes de Atendimento à mulher em situação de violência doméstica como protagonista de uma ação estatal, cuja deficiência poderá tornar a Lei Maria da Penha uma falácia.

Ademais, especificamente no contexto do caso aqui explorado, este se insere em uma realidade em que são noticiados, por parte da Secretaria de Estado da Mulher, planos e programas visando o enfrentamento das desigualdades e a defesa dos direitos das mulheres e, ainda, a intenção de se estabelecer diálogos com os demais setores da sociedade civil e órgãos públicos como o Poder Judiciário na concretude das políticas públicas estaduais e municipais de enfrentamento da violência contra a mulher.

Entretanto, numa aproximação mais objetiva do caso que conduziu o presente estudo, é possível diagnosticar que a Lei Maria da Penha foi contundentemente desconsiderada para efeito de objetivamente tratar com acuidade necessária o tipo de violência em que inseridos vítima e agressor e as peculiaridades relativas à sua manifestação. E em assim sendo, seu desfecho não poderia ser mais lesivo ou iatrogênico: culminou com um feminicídio e um suicídio.

Desprestigiadas tais peculiaridades, está-se assim diante de um Judiciário que julga sem atentar para o 
marco legal que abriga a cidadania da mulher e sua proteção integral contra a violência a que vem secularmente sendo submetida.

Compreende-se a visão de integralidade na assistência à mulher vitimada pela violência, admite-se e reconhece-se que a construção desta tarefa é obra que não se restringe ao hermetismo das práticas judicializantes, mas admite que sua elaboração se dê a partir da dinâmica social de serviços especializados e sua organização em rede, que absorva ações voltadas à vítima e ao agressor, bem como a partir da devida qualificação da magistratura em acessar e fazer funcionar essas redes para sua eficiente atuação em causas que envolvam violência doméstica.

O assassinato de M. N. S. S, seguido do suicídio de A. C. C., chama a refletir sobre de que modo o Estado tem atuado no que tange à estruturação dos três eixos de enfrentamento à violência contra mulher, segundo prescrito na Lei 11.340/06.

Decerto que esta estruturação demanda a integração de equipes multidisciplinares que promovam uma intersetorialidade de ações que se configurem na contramão das hierarquias postas entre o Judiciário e os demais saberes.

Trata-se de uma conjunção de atividades que abarquem todas as interfaces do fenômeno da violência contra a mulher, mediante a configuração de um quadro técnico (assistentes sociais, psicólogos e demais profissionais da saúde, pedagogos, etc), inseridos profissionalmente no âmbito Política Nacional de Enfrentamento à Violência Contra as Mulheres.

Todavia, aquela estrutura só poderá abarcar este fenômeno se encontrar no Judiciário uma eficaz apropriação da norma em espécie, assumindo uma mudança de concepção a abranger novos paradigmas em sua capacitação para o fim de enfrentar, coibir, prevenir e reduzir a violência contra a mulher.

\title{
DYSFUNCTIONAL PERCEPTION OF THE PERPETRATOR IN THE MARIA DA PENHA LAW: TOLERANCE AND INVISIBILITY IN A CONTINUITY SYSTEM
}

\begin{abstract}
This paper seeks to examine the Judiciary's dysfunctional perception of the domestic aggressor figure and how it supports an underperformance of the guarantees contained in the n. 11340/06 law. It explores the obstacles observed in relation to that justice sistem, when it acts upon this kind of norm, evaluating its protagonism in accessing and operating the Care Networks for women in violence situation. It highlights the existence of a normativist and technical-bureaucratic legal culture, based on an empirical data present in the analysis of a decision that revoked the preventive detention of a domestic aggressor and its consequences. The methodology consists of bibliographical and documentary research. The problem that arises in this work is: how clearly does the judiciary deal with the mechanisms adopted for punishing, preventing and eradicating violence against women?
\end{abstract}

Keywords: Maria da Penha Law; Gender Violence; The aggressor invisibility; Comprehensive Care; Service 
networks.

\section{REFERENCIAS}

ASSOCIAÇÃO DOS MAGISTRADOS DO MARANHÃO. AMMA posiciona-se em defesa de juíza após tragédia ocorrida em Pedreiras. Disponível em <http://www.amma.com.br/noticias 1,5060 „,amma-posicionase-em-defesa-de-juiza-apos-tragedia-ocorrida-em-pedreiras $\geq$. Acesso em 14.dez.2015.

BRASIL. Constituição (1988). Constituição da República Federativa do Brasil. Brasília: Senado, 2009.

Código Penal. Decreto-Lei no 2.848, de 7 de dezembro de 1940. Vade mecum. São Paulo: Saraiva, 2015.

Código de Processo Penal. Decreto-Lei no 3.689, de 3 de Outubro de 1941. Vade mecum. São Paulo:

Saraiva, 2015.

Lei Maria da Penha. Lei n. ${ }^{11}$ 1.340, de 7 de Agosto de 2006. Brasília: Senado, 2012.

Rede de Enfrentamento à Violência Contra as Mulheres, 2011a. Brasília: Senado, 2014.

Política Nacional de Enfrentamento à Violência Contra as Mulheres, 201 lb. Brasília: Senado, 2014.

Juizados Especiais Cíveis e Criminais. Lei n. 9.099, de 26 de setembro de 1995. Brasília: Senado, 2009.

Superior Tribunal de Justiça. Habeas Corpus n.o 123.804 - MG (2008/0276709-4), - Minas Gerais.

Relator: Ministro Felix Fisher.Pesquisa de Jurisprudência, Acórdãos, 17 de março de 2009. Disponível em: < http://www.compromissoeatitude.org.br/wp-content/uploads/2013/05/STJ_HC123804_MG_126419145 1011.pdf>. Acesso em: 17 fev. 2016.

Maranhão. Tribunal de Justiça do Estado do Maranhão. Violência Doméstica contra a Mulher: Dados Estatísticos da Vara Especializada da Comarca de São Luís. Março de 2015. Disponível em: $<$ http://gerenciador.tjma.jus.br/app/webroot/files/publicacao/408366/relatorio_pesquisa_social_2015_100 32015_1332.pdf $\geq$. Acesso em 06.dez.2015.

Maranhão. Tribunal de Justiça do Estado do Maranhão. Enunciados FONAVID. Disponível em <http://gerenciador.tjma.jus.br/app/webroot/files/publicacao/407046/enunciados_fonavid_11112014_110 4.pdf>. Acesso em 18.dez.2015.

Maranhão. Pedreiras. Secretaria Municipal de Políticas para as Mulheres. Plano Municipal De Políticas para as Mulheres Pedreiras - Maranhão Plurianual 2014-2017. Disponível em: < http://www.semu.ma.gov.br/files/2014/05/PEDREIRAS.pdf >. Acesso em 02.fev.2017

Maranhão. Carta de Serviços Rede Estadual de Atendimento às Mulheres em Situação de Violência, 2014. Disponível em: < http://www.semu.ma.gov.br/files/2014/10/CARTA-DE-SERVI\%C3\%87OS-OUT14.pdf $>$. Acesso em 02.fev.2017

Maranhão. Secretaria da Mulher - SEMU. A Semu realiza diálogos para fortalecimento do Enfrentamento à Violência contra as Mulheres, 2014. Disponível em: < http://www.semu.ma.gov.br/a-semurealiza-dialogos-para-fortalecimento-do-enfrentamento-a-violencia-contra-as-mulheres/>. Acesso em 02.fev.2017

CAMPOS, Carmen Hein de. Razão e Sensibilidade: Teoria Feminista do Direito e Lei Maria da Penha. Disponível em: <http://www.homolog.compromissoeatitude.org.br/ wp-content/uploads/2014/02/1_1_ razao- e-sensibilidade.pdf.> Acesso em 21.mar.2016.

CELMER, Elisa Girotti. DE AZEVEDO, Rodrigo Ghiringhelli. Violência de gênero, produção legislativa e discurso punitivo - Uma análise da lei no 11.340/2006. BOLETIM IBCCRIM - ANO 14 - No 170 - JANEIRO 2007. Disponível em: <http:/ /www.homolog.compromissoeatitude.org.br/wp- content/uploads/2014/02/

Boletim-170_Azevedo.pdf. Acesso em 19.fev.2016>. 
D’OLIVEIRA, Ana Flávia Pires Lucas; SCHRAIBER, Lilia Blima. Mulheres em situação de violência: entre rotas críticas e redes intersetoriais de atenção. Revista de Medicina, v. 92, n. 2, p. 134-140, 2013. Disponível em: < http://www.journals.usp.br/revistadc/article/view/79953/83887>. Acesso em 02.fev.2017.

FONAVID. Fórum Nacional de Juízes de Violência Doméstica e Familiar contra a Mulher. Disponível em $<$ http://www.amb.com.br/fonavid/ $\geq$. Acesso em 18.dez.2015.

FREITAS, Lúcia. Análise Crítica do Discurso em Dois Textos Penais Sobre a Lei Maria da Penha. Alfa, São Paulo, 57 (1): 11-35, 2013. Disponível em: <http://www.scielo.br/pdf/alfa/v57n1/02.pdf.> Acesso em 17.dez.2015.

JORNAL O IMPARCIAL. Homem é liberado da prisão e sequestra e mata ex-namorada em pedreiras. Disponível em: <http://www.oimparcial.com.br/_conteudo/2015/08/ultimas_noticias/urbano/178889homem-e-liberado-da-prisao-e-sequestra-e-mata-ex-namorada-em-pedreiras.html.> Acesso em 14.dez.2015.

MACHADO, Isadora Vier. Da dor no corpo à dor na alma: uma leitura do conceito de violência psicológica da Lei Maria da Penha. 2013. 278 f. Tese (Doutorado em Ciências Humanas) - Centro de Filosofia e Ciências Humanas, Universidade Federal de Santa Catarina, Florianópolis. 2013.

MACIEL, Débora Alves. Ação coletiva, mobilização do direito e instituições políticas: o caso da campanha da lei Maria da Penha. Rev. bras. Ci. Soc. [online]. 2011, vol.26, n.77 [cited 2016-03-21], pp.97-112. Available from: $<$ http://www.scielo.br/scielo.php?script=sci_arttext\&pid=S0102-6909201 1000300010\&lng=en\&nrm=iso>. ISSN 0102-6909. http://dx.doi.org/10.1590/S0102-69092011000300010. Acesso em 21.mar.2016.

MINISTÉRIO PÚBLICO DO MARANHÃO. Aplicação da Lei Maria da Penha no Maranhão é debatida em audiência pública. Disponível em: <http://www.mpma.mp.br/index.php/lista-de-noticias-gerais/3335-noticiaaplicarro-da-lei-maria-da-penha-no-maranhro-r-debatida-em-audirncia-prblica>. Acesso em: 18.dez.2015.

PARENTE, Eriza de Oliveira; NASCIMENTO, Rosana Oliveira do; VIEIRA, Luiza Jane Eyre de Souza. Enfrentamento da violência doméstica por um grupo de mulheres após a denúncia. Revista Estudos Feministas, v. 17, n. 2, p. 445-465, 2009. Disponível em: < http://www.scielo.br/scielo.php?script=sci_arttext\&pid=S0104026X2009000200008\&lng=en\&nrm=iso\&tlng=pt $>$. Acesso em 02.fev.2017

PASINATO. Wânia. Lei Maria da Penha. Novas abordagens sobre velhas propostas. Onde avançamos? Civitas Porto Alegre v. 10, n. 2, p. 216-232, maio-ago. 2010. Disponível em $<$ http://revistaseletronicas.pucrs.br/ojs/index.php/civitas/article/view/6484/5603 2 . Acesso em 06.dez.2015.

POUGY, Lilia Guimarães. Desafios políticos em tempos de Lei Maria da Penha. Rev. Katálysis. Florianópolis v. 13 n. 1 p. $76-85$ jan./jun. 2010. Disponível em: <http://www.scielo.br/pdf/rk/v13n1/09.pdfz. Acesso em 20.dez.2016.

ROULAND, Norbert. Nos Confins do Direito. São Paulo: Martins Fontes, 2008.

SANTOS, Boaventura de Sousa. Para uma Revolução Democrática da Justiça. São Paulo: Cortez, 2007.

SCIAMMARELLA, Ana Paula de Oliveira, FRAGALE FILHO, Roberto. (Des)constituindo gênero no poder judiciário. Ex aequo [online]. 2015, n.31, pp. 45-60. ISSN 0874-5560. Disponível em http://www.scielo.mec.pt/scielo.php?script=sci_abstract\&pid=S0874-

$55602015000100005 \& \operatorname{lng}=$ en\&nrm=iso\&tlng=pt $>$ Acesso em 14.mar.2016 
SEGATO, Rita Laura. Las estructuras elementales de la violencia. Ensayos sobre género entre la antropología, el psicoanálisis y los derechos humanos. Bernal, Universidad de Quilmes, 2003.

SCHRAIBER, Lilia Blima; PIRES, Ana; KISS, Ligia. Assistência a mulheres em situação de violência da trama de serviços à rede intersetorial. Athenea Digital: revista de pensamiento e investigación social, v. 12, n. 3, p. 237-254, 2012. Disponível em: < https://dialnet.unirioja.es/servlet/articulo?codigo=4154834> Acesso em: 01.fev.2017

SILVA, Luciane Lemos. COELHO, Elza Berger Salema. CAPONI, Sandra Noemi Cucurullo. Violência silenciosa: violência psicológica como condição da violência física doméstica. Interface - Comunic., Saúde, Educ., v.11, n.21, p.93-103, jan/abr 2007. Disponível em: <http://www.scielo.br/pdf/\%0D/icse/v1 ln21/v1ln21a09.pdf. Acesso em 06.dez.2015>.

TJMA. Vara Especial de Violência Doméstica e Familiar Contra a Mulher, de São Luís, Maranhão. Processo no 1381-53.2015.8.10.0005. Juiz de Direito Nelson Melo de Moraes Rêgo. Sentença 14/08/2015.

Terceira Vara de Pedreiras, Maranhão. Processo n 1952-80.2015.8.10.0051. Revogação de Prisão $04 / 08 / 2015$

VERAS, Érica Verícia Canuto de Oliveira. As Hipóteses de Prisão Preventiva da Lei Maria da Penha na Visão do Superior Tribunal de Justiça. Ministério Público de Minas Gerais. Disponivel em: <https://aplicacao.mpmg.mp.br/xmlui/bitstream/handle/123456789/1182/R\%20DJ\%20

\%20Comentario\%20hipoteses\%20de\%20prisao\%20-\%20Erica.pdf?sequence=1 . Acesso em 17.dez.2015.

WAISELFISZ, Julio Jacobo. Mapa da Violência 2015: Homicídio de Mulheres no Brasil. Flacso.org: Brasília, 2015. Disponível em: < http://www.mapadaviolencia.org.br/pdf2015/MapaViolencia_2015_mulheres.pdf >. Acesso em 02.fev.2017

Trabalho enviado em 02 de setembro de 2016.

Aceito em 08 de fevereiro de 2017. 